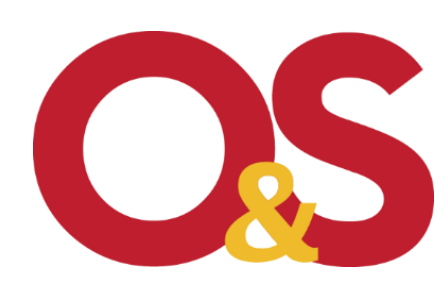

Editorial

\section{Educational Impact of Research}

\author{
Marcelo de Souza Bispo ${ }^{\mathrm{a}}$ \\ Eduardo Paes Barreto Davel ${ }^{b}$ \\ a Universidade Federal da Paraíba, João Pessoa, Brazil \\ b Universidade Federal da Bahia, Salvador, Brazil
}

\section{Journal Organizações \& Sociedade \\ 2021, 28(97), 233- 240 \\ (C) Authors 2021 \\ DOI 10.1590/1984-92302021v28n9700EN \\ ISSN 1984-9230 \\ www.revistaoes.ufba.br NPGA, School of Management Federal University of Bahia}

\begin{abstract}
To think about the impacts of academic research on education is to think dynamically: education affects the ways of doing research (from the point of view of formal education) and is affected by research results that are little predictable and perceived due to constant negotiations among social actors in their daily socializations in different contexts. Management education (formal, non-formal and informal) affects and is affected by conflicting views of the world, which are produced within the field of management itself and whose impact as "beneficial" is not just a matter oriented primarily by economic, instrumental and financial aspects, but also for a negotiated understanding of the world that moves towards the common good. All research must be concerned with its power to affect educational vision and practice, directly or indirectly. How can this concern become perennial and central to the practice of academic research?
\end{abstract}

Keywords: impact; research; education; affect.

\title{
Introduction
}

Despite being two distinct fields, research and education are often confused in academic contexts such as graduate studies. Especially in the Brazilian context, there is an understanding that graduate education is the space for research (Bispo, 2020a). However, research and education often follow different roads outside the university environment - especially that of graduate studies. Part of this gap between research and education comes from the understanding that research is a private 
amusement park for some scholars without direct implications for society. One may find some exceptions in the areas of health sciences and technology, while education is limited to classroom teaching. In this sense, academic research seems to contribute little to education or to other aspects of social life. It is based on this understanding - one that is shared by many in society and by some scholars - that we consider necessary and pertinent to discuss the impact of research on education under multiple dimensions.

Although some authors (Coordenação de Aperfeiçoamento de Pessoal de Nível Superior, 2019; Godin \& Doré, 2005; Sandes-Guimarães \& Hourneaux Junior, 2020) recognize that education can be impacted by scientific research, their considerations end up emphasizing only the issues of teaching and learning. Consequently, they leave aside the political, cultural and social aspects of education that influence the organization of societies (Althusser, 1985 Bourdieu \& Passeron, 1992; Bruner, 1996; Laval, 2004; Libâneo, 2010). In other words, we lack academic research that includes in its results a reflection on its educational impact in a broader sense: immediate, operational, comprehensive, indirect, cultural, political, social, among others.

Moreover, we must consider that education is not limited to the school context (Gohn, 2016; Luckesi, 2011) and is practiced in other organizations such as the family, church, businesses and non-governmental organizations. Thus, the impact of scientific research on education can be greater than what is usually estimated. The Covid-19 pandemic contributed to show how, for example, research on the Sars-CoV-2 virus and the disease itself generated knowledge about hand hygiene, the use of masks and rubbing alcohol, among others. We thus see direct impacts on the ways of practicing education both in the school context with changes in teaching methods and in learning and living with education inside and outside the school environment (for example, the implications of remote education for students, teachers and families). New impacts on the educational context are yet to be discovered with the advances of vaccine development and vaccination itself.

However, what are we calling the impact of research? Despite being a topic that has taken over the academic environment and government funding and control bodies in recent years (Donovan, 2011; Gunn \& Mintrom, 2017), debates about what impact is remain a pressing issue. Unlike the dominant views on the topic (Sandes-Guimarães \& Hourneaux Junior, 2020), we propose the understanding of research impact as a form of affect (Gherardi, 2017, 2019; Massumi, 2002). While the understanding of the dominant view on "impact" moves in the direction of "positive effects from research on society", we defend a more relativistic position on the "effects" of research by assuming that they can be "positive" or "negative" depending on the point of view. After all, defining what is good for society always bears some controversy (Gunn \& Mintrom, 2017).

The impact of research can be perceived as affect because it generates emotions that are directly linked to the practice of research. We thus understand that a social practice is the result of collective accomplishments enacted from the connections of bodies, materialities, discourses and knowledge (Bispo, 2020b; Gherardi, 2019). Affect is related to the capacity (agency) that human and non-human actors have to affect and be affected by each other (Massumi, 2002). From this perspective, we challenge both assumption: (a) effects of a research's impact as "beneficial" and (b) impact goes through a single direction (from research (University) to society). In other words, the impact is the result of the continuous relationship between research and society in which both affect each other, mutually. Research practice thus affects multiple aspects of society that also affect research practice itself. 
Another dimension that we cannot overlook is that the main association of research impact is made with economic gains (Edwards \& Meagher, 2020; Pitman \& Berman, 2009), such idea conceals an appropriation of the term "impact" by the current neoliberal rationality (Dardot \& Laval, 2016), given that the term usually presents itself as a technical and neutral issue in its purposes and propositions (Harvey, 2005). It is precisely because of the dominance of neoliberal rationality in Western societies (and part of Eastern ones too) that the pressure for financial impacts resulting from research (Pitman \& Berman, 2009) increasingly dominates the valuation of research with immediate economic, instrumental and financial impacts. At the same time, cultural, social, political and educational impacts are put in check on their "social" quality and usefulness (Jack, 2020). Associating the impacts of research with the financialization of the contemporary world (Paulani, 2006) consists of establishing the end of research itself as a broad social practice, which creates other possibilities of understanding it, in addition to financial, instrumental and economic aspects.

To think about the impact of academic research on education is, therefore, to think dynamically: education affects the forms of research (from the point of view of formal education), as much as it is affected by research results that are not very predictable and perceived due to the constant negotiations between social actors in their daily socializations in different contexts. The educational impact of research thus refers to its unfolding in the scope of broader teaching-learning practices and school environments, that is, in the very research environment, on researchers themselves and in the contexts of informal and non-formal education (Gohn, 2016) that are found in other organizational forms. We can thus think of education as an organizational phenomenon of society in its multiple forms of sociability.

\section{Educational dimension of society and organizations}

Education is intrinsic to the social organization of any society. Education is responsible for the socialization processes that create, reproduce and change the rules of social coexistence, as well as for establishing forms of discipline, control and punishment. Education happens through experiences that can be educational. The quality of experiences shapes the quality of education, meaning that not every experience can be considered educational (Dewey, 1963). Although education is usually associated with school, school education is only one of the forms of its manifestation known as formal education (Luckesi, 2011). There is also non-formal education that takes place in organizations such as companies, churches and associations, as well as informal education that happens in environments where family and friends are present (Gohn, 2016). If education is a social practice that permeates all possibilities for socialization, our daily living is the result of these multiple educational possibilities. Thus, we educate and are educated constantly, regardless of being in an institutionalized school environment (Freire, 1974).

Within the scope of organization studies and management, education is present in formal contexts such as business schools, non-formal ones such as corporate universities, and informal such as in interactions that occur in different departments and organizational events environments, for example. However, the idea of education (with some exceptions) is little used among researchers in the field of management when we compare it with the notions of learning and skills that are always present in debates and productions. In this sense, the notion of education in management debate is very restricted to the context of business schools and to the possibilities of teaching and learning 
within them (Arbaugh, 2016). Still in the context of business schools, it is not uncommon to use the Portuguese word "treinamento" (which can be directly translated as "training", although it often bears a negative connotation in Portuguese) as a synonym for education, reducing management education (including in graduate school) to the reproduction of techniques and the development of specific skills, disregarding the need for critical thinking of the world and the role of work in the context of the experience.

The educational impact of research on society and organizations requires rethinking how problems resulting from research within the field itself can be solved. We have known for some time that the humanities and social sciences have a privileged place in the process of rethinking management education (Gagliardi \& Czarniawska, 2006; Izak, Kostera, \& Zawadzki, 2017; Landfester \& Metelmann, 2019; Steyaert, Beyes, \& Parker, 2016) and in the development of fully aware, responsible and engaged leaders for the common good (Muff et al., 2013), since character, citizenship, collaboration and critical thinking are recognized as essential competences (Fullan, Quinn, \& McEachen, 2018) for contemporary life. For example, we know that entrepreneurs develop activities that challenge the status quo, break rules and subvert systems (Bureau \& KomporozosAthanasiou, 2016). However, how has this research result been affecting management education? And vice versa: how does research include these types of educational concerns in its research processes and consciousnesses?

Among all inconsistencies between research results and their ability to affect society educationally, one conflict stands out as central: the tension between the individualistic logic of maximizing profits and the demands for business ethics, sustainability and corporate social responsibility (Eury \& Treviño, 2019; Zanoni, Contu, Healy, \& Mir, 2017). Management research (academia and market) must advance in the debate and in the solution of this conflict since the creation of the principles for responsible management education by the United Nations remain very theoretical and restricted to an isolated content that is taught in business schools without presenting well-defined and relevant results (Millar \& Price, 2018). The debate on how to articulate the conflict between profit maximization with non-financial demands in the search of responsible management (Laasch \& Gherardi, 2019) is a challenge that highlights the affective relationship that exists in ways of educating in the field of management and the very practice of managing itself. Thus, could a way of advancing this issue consist of expanding the concept of education beyond formal contexts and transforming management itself as a fundamentally educational practice?

\section{Educational impact of academic research}

Perceived as affects, the impacts of academic research help to broaden the understanding that results are not always beneficial. At the same time, they are not unidirectional since research impacts (affects) society (including academia) and is impacted (affected) by it. The creation of the principles for responsible management education by the United Nations shows how the impact of research is not only a relation (or lack of it) between theory and practice, but hightlights the need to find ways to solve (or mitigate) the conflicts existing within the management field of knowledge itself from scientific results that point out to different paths. Management education (formal, nonformal and informal) thus affects and is affected by conflicting worldviews produced within the management field in which the impact as "beneficial" is not just an issue guided primarily by 
economic, instrumental and financial aspects, but also for a negotiated understanding of the world that moves towards the common good (Muff et al., 2013).

This context opens space for us to rethink how the debate on the impact of research has generated affects that are still poorly conceived and discussed. All research must be concerned with its power to affect educational vision and practice, directly or indirectly, immediately or in broader terms. How can this concern become perennial and central to the practice of academic research? How do the results of the understanding of impact guided by a neoliberal bias affect the research agendas and researchers themselves? How do the multiple ways of generating knowledge affect the process and fundamentals of management education? How do the results of academic research affect education in non-school settings (such as family, church and business)? How can we transform management research into a substantially educational practice? These questions invite us to engaje in an agenda of debates, research and reflections that broaden the scope of the discussion both in management education and in managers' practice itself. To neglect this agenda is to ignore the debate about the impact of research and how it may be able to resolve more vital aspects of organized social life.

\section{References}

Althusser, L. (1985). Aparelhos ideológicos de estado: Nota sobre os aparelhos ideológicos de estado (3rd ed). Rio de Janeiro, RJ: Graal.

Arbaugh, J. (2016). Where are the dedicated scholars of management learning and education? Management Learning, 47(2), 230-240. doi:10.1177/1350507615595773

Bispo, M. (2020a). Contradições da pós-graduação em administração brasileira. Revista Eletrônica de Ciência Administrativa, 19(2), 169-180. doi:10.21529/RECADM.2020007

Bispo, M. (2020b). Silvia Gherardi's influence on practice-based studies and organizational research. Qualitative Research in Organizations and Management, 15(4), 561-565. doi: 10.1108/QROM-11-2019-1857

Bourdieu, P., \& Passeron, J. C. (1992). A reprodução. (3rd ed). Rio de Janeiro, RJ: Francisco Alves.

Bruner, J. (1996). The culture of education. Cambridge: Harvard University Press.

Bureau, S., \& Komporozos-Athanasiou, A. (2016). Learning subversion in the business school: An 'improbable' encounter. Management Learning, 48(1), 39-56. doi:10.1177/1350507616661262

Coordenação de Aperfeiçoamento de Pessoal de Nível Superior. (2019). GT impacto e relevância econômica e social: Relatório Final de Atividades, Brasília, DF: CAPES.

Dardot, P., \& Laval, C. (2016). A nova razão do mundo. São Paulo, SP: Boitempo.

Dewey, J. (1963). Experience and Education. New York: Collier Books.

Donovan, C. (2011). State of the art in assessing research impact: introduction to a special issue. Research Evaluation, 20(3), 175-179. doi:10.3152/095820211X13118583635918 
Edwards, D. M., \& Meagher, L. R. (2020). A framework to evaluate the impacts of research on policy and practice: a forestry pilot study. Forest Policy and Economics, 114, 101975. doi:10.1016/j.forpol.2019.101975

Eury, J. L., \& Treviño, L. K. (2019). Building a Culture of Honor and Integrity in a Business School. Journal of Management Education, 43(5), 484-508. doi:10.1177/1052562919850223

Freire, P. (1974). Pedagogia do oprimido. São Paulo, SP: Paz e Terra.

Fullan, M., Quinn, J., \& McEachen, J. (2018). Deep learning: engage the world, change the world. Thouasand Oaks: Sage Publications.

Gagliardi, P., \& Czarniawska, B. (Eds.). (2006). Management education and humanities. Cheltenham: Edward Elgar.

Gherardi, S. (2017). Which is the place of affect within practice-based studies? M@n@gement, 20(2), 208-220. Recuperado de https://bit.ly/32e3g17

Gherardi, S. (2019). How to conduct a practice-based study: problems and methods (2nd ed). Cheltenham: Edward Elgar.

Godin, B., \& Doré, C. (2005). Measuring the impacts of science: beyond the economic dimension. Helsinki: Helsinki Institute for Science and Technology Studies. Retrieved from https://bit.ly/3dRi8YS

Gohn, M. G. (2016). Educação não-formal nas instituições sociais. Revista Pedagógica, 18(39), 5975. doi:10.22196/rp.v18i39.3615

Gunn, A., \& Mintrom, M. (2017). Evaluating the non-academic impact of academic research: design considerations. Journal of Higher Education Policy and Management, 39(1), 20-30. doi:10.1080/1360080X.2016.1254429

Harvey, D. (2005). A Brief History of Neoliberalism. Oxford: Oxford University Press.

Izak, M., Kostera, M., \& Zawadzki, M. (Eds.). (2017). The Future of University Education. London: Palgrave Mcmillan.

Jack, A. (2020, 24th February). Academic focus limits business schools' contribution to society. Financial Times. Retrieved from https://on.ft.com/3wMHArd

Laasch, O., \& Gherardi, S. (2019, August). Responsible management, learning, and education: a research agenda through a social practices lens. Academy of Management Annual Meeting. Retrieved from https://bit.ly/3wll9Cp

Landfester, U., \& Metelmann, J. (2019). Transformative Management Education: The Role of the Humanities and Social Sciences. New York: Routledge.

Laval, C. (2004). A escola não é uma empresa: O Neo-liberalismo em ataque ao ensino público. Londrina, PR: Planta.

Libâneo, J. C. (2010). Pedagogia e pedagogos, para quê? (12nd ed). São Paulo, SP: Cortez.

Luckesi, C. C. (2011). Filosofia da educação (3rd ed). São Paulo, SP: Cortez. 
Massumi, B. (2002). Parables for the Virtual: Movement, Affect, Sensation. Durham: Duke University Press.

Millar, J., \& Price, M. (2018). Imagining management education: a critique of the contribution of the United Nations PRME to critical reflexivity and rethinking management education. Management Learning, 49(3), 346-362. doi:10.1177/1350507618759828

Muff, K., Dyllick, T., Drewell, M., North, J., Shrivastava, P., \& Haertle, J. (2013). Management education for the world: a vision for business schools serving people and planet. Cheltenham: Edward Elgar.

Paulani, L.M. (2006). O projeto neoliberal para a sociedade brasileira: sua dinâmica e seus impasses. In J. C. F. Lima, \& L. M. W. Neves (Orgs), Fundamentos da educação escolar do Brasil contemporâneo (pp. 67-107). Rio de Janeiro, RJ: Editora Fiocruz.

Pitman, T., \& Berman, J. (2009). Of what benefit and to whom? Linking Australian humanities research with its 'end users.' Journal of Higher Education Policy and Management, 31(4), 315326. doi:10.1080/13600800903191955

Sandes-Guimarães, L. V., \& Hourneaux Junior, F. (2020). Editorial: Research impact - what is it, after all? Editorial impact series part 1. RAUSP Management Journal, 55(3), 283-287. doi: 0000-0002-0165-7843

Steyaert, C., Beyes, T., \& Parker, M. (Eds.). (2016). The Routledge Companion to Reinventing Management Education. London: Routledge.

Zanoni, P., Contu, A., Healy, S., \& Mir, R. (2017). Post-capitalistic politics in the making: the imaginary and praxis of alternative economies. Organization, 24(5), 575-588. doi: $10.1177 / 1350508417713219$

\section{Authorship \\ Marcelo de Souza Bispo}

Ph.D. in management from the Universidade Presbiteriana Mackenzie, with a post-doctorate research in social theory from the Universidade de Kentucky (EUA). Professor at the Management Department and co-leader of the Núcleo de Estudos em Aprendizagem e Conhecimento (NAC-UFPB) at the Universidade Federal da Paraíba. Associate editor of the Organizações \& Sociedade journal, axis "organizations and education". He researches and publishes in the field organizational theory, education and tourism.

E-mail: marcelodesouzabispo@gmail.com

ORCID: https://orcid.org/0000-0002-5817-8907

\section{Eduardo Paes Barreto Davel}

Ph.D. in management from École des Hautes Études Commerciales de Montréal (Canada), with a post-doctorate research in Management from the Nova School of Business and Economics at Universidade Nova de Lisboa (Portugal). Professor at the School of Management at the Federal 
University of Bahia, Brazil. Editor-in-chief of Organizações \& Sociedade journal. He researches and publishes on cultural entrepreneurship, creative process management, teaching, methods, learning, culture, and aesthetics in organizations.

E-mail: davel.eduardo@gmail.com

ORCID: https://orcid.org/0000-0003-0610-6474

\section{Authors' contributions}

First author: conceptualization (equal), investigation (equal), writing-original draft (equal).

Second author: conceptualization (equal), investigation (equal), writing-original draft (equal).

O\&S is signatory to DORA (The Declaration on Research Assessment) and to COPE (Committee on Publication Ethics).

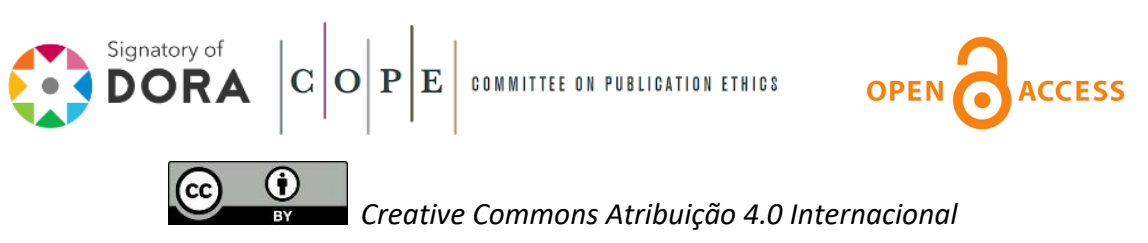

